\title{
Comparisons of Bully and Unwanted Sexual Experiences Online and Offline Among a National Sample of Youth
}

\author{
Michele L. Ybarra, Kimberly J. Mitchell \\ and Dorothy L. Espelage \\ Internet Solutions for Kids, Inc, University of Illinois,
}

USA

\section{Introduction}

A dramatic increase in Internet use among young people in the past decade (Lenhart, 2009) has contributed to a heightened appreciation for the Internet's potential positive (Lenhart, 2009; Rideout, 2001; Ybarra \& Suman, 2008) and negative impacts (Guan \& Subrahmanyam, 2009; Juvonen \& Gross, 2008; Katzer, Fetchenhauer, \& Belschak, 2009; Li, 2006; Mitchell, Finkelhor, \& Wolak, 2001, 2007; Raskauskas \& Stoltz, 2007; Slonje \& Smith, 2008; Smith et al., 2008; Wolak, Mitchell, \& Finkelhor, 2006; Ybarra, Diener-West, \& Leaf, 2007a; Ybarra, Leaf, \& Diener-West, 2004) on the health and development of youth. Internet harassment and bullying victimization have received particular research attention, and are consistently found to be associated with psychosocial problems including depressive symptoms, poor caregiver-child relationships, social and behavior problems, and substance use (Guan \& Subrahmanyam, 2009; Juvonen \& Gross, 2008; Katzer et al., 2009; Li, 2006; Raskauskas \& Stoltz, 2007; Slonje \& Smith, 2008; Smith et al., 2008; Wolak et al., 2006; Ybarra et al., 2007a). Unwanted online sexual solicitation, defined as being asked to talk about sex, provide personal sexual information, or do something sexual when the youth does not want to when using the Internet, is another area of adolescent health concern. Online sexual solicitation has been associated with psychosocial challenges including depressive symptomatology (Mitchell et al., 2001, 2007; Ybarra et al., 2004).

Certainly, the Internet is but one environment in which youth must navigate. Victimization has been noted particularly at school, where youth spend a great deal of their time. Studies consistently report that victims of school bullying are significantly more likely to experience negative health and social consequences than non-bullied youth, including health problems, emotional and school adjustment problems, and poorer peer relationships (Due et al., 2005; Hawker \& Boulton, 2000; Nansel et al., 2004; Sourander, Helstela, Helenius, \& Piha, 2000). Unwanted sexual experiences in the schools is similarly associated with psychosocial problems, including alcohol use (Fineran \& Bolen, 2006).

Many studies have reported relative rates of bullying online and offline (Juvonen \& Gross, 2008; Katzer et al., 2009; Li, 2006; Raskauskas \& Stoltz, 2007; Slonje \& Smith, 2008; Smith et al., 2008; Wang, Iannotti, \& Nansel, 2009); most report bullying more commonly occurring in 
the schools. These studies use varying definitions for online and offline bullying and/or focus on regional or convenience samples. Furthermore, rates in non-school environments are not reported. Little has been reported in terms of bullying perpetration across environments also. Of note, Wang and colleagues (Wang et al., 2009) report that among 6$10^{\text {th }}$ graders nationally, $8 \%$ bully others online, $27 \%$ bully others socially, $37 \%$ bully verbally, and $13 \%$ bully others physically while at school. Online bullying is treated as a different type of bullying however; such that, for example, social bullying that occurs online is imperfectly measured. Importantly too, data are lacking about how the bullying experience may differ online versus offline. No data have been presented to compare relative rates of distress for bullying that occurs online versus offline. It also has been posited that a unique aspect of online bullying is the potential for anonymity; this assumes that all victims know their offline bullies. No research has examined however, whether this is a valid assumption.

Even less has been reported about unwanted sexual experiences online and offline. Ybarra and colleagues (Ybarra, Espelage, \& Mitchell, 2007b) report overlaps in victimization for harassment and unwanted sexual experiences online; they do not report however, the relative rates of unwanted sexual experiences online and offline. To our knowledge, no other studies have reported relative rates of online and offline unwanted sexual solicitation in the general population of youth.

To address these gaps in the literature, we report data from the Growing up with Media study, a national survey of over 1,000 youth. Findings have implications for public policy initiatives as well as school and other community-based intervention efforts.

\section{Methods}

The Growing up with Media study is a longitudinal survey examining the associations between exposure to violent media - particularly new media (e.g., the Internet) - and violent behavior. Wave 1 data were collected August-September, 2006 with 1,588 youth-caregiver pairs; data were collected again November, 2007 - January 10, 2008 [Wave 2, $(n=1,206)$ ] and August - November, 2008 [Wave 3, $(n=1,159)$ ]. The survey protocol was reviewed and approved by the Centers for Disease Control and Prevention Institutional Review Board (IRB).

The sample was obtained from the Harris Poll Online (HPOL) opt-in panel (Harris Interactive, 2006), which is comparable to random telephone samples of adult populations once appropriate sample weights are applied (Berrens, Bohara, Jenkins-Smith, Silva, \& Weimer, 2003; Berrens, Bohara, Jenkins-Smith, Silva, \& Weimer, 2004; Schonlau et al., 2004; Taylor, Bremer, Overmeyer, Siegel, \& Terhanian, 2001). Recruitment was balanced on youth age and sex. Participants were recruited through an email contact with randomly identified adult HPOL members who had previously indicated a child lived in the household. Adult respondents (one per household) were required to be equally or more knowledgeable than other adults in the home about the youth's media use, and to provide consent for their participation and permission for their child's participation. Youth participants were required to be 10-15 years old, read English, live in the household at least $50 \%$ of the time, have used the Internet in the last 6 months, and provide assent to participate in research. 
On average, adult surveys lasted 5-minutes and youth surveys 21 minutes. Youth received a $\$ 20$ gift certificate and caregivers a $\$ 15$ check for their participation at Waves 1 and 2; and $\$ 25$ and \$20, respectively at Wave 3. The surveys were administered by Harris Interactive.

\subsection{Sample}

Although parallel questions of bullying online and offline were added at Wave 2, it was not until Wave 3 that measures of perpetration and distress were added. To fully answer the research questions posed, the current analyses are restricted to Wave 3. The baseline survey response rate, $26 \%$, was within the expected range of similar online surveys (Cook, Heath, \& Thompson, 2000; Kaplowitz, Hadlock, \& Levine, 2004).

To maximize data, respondents were invited to take part in the Wave 2 and Wave 3 surveys irrespective of their participation at previous Waves. Response rates were $76 \%$ and $73 \%$ of baseline participants at Wave 2 and Wave 3, respectively. Survey participants in subsequent Waves were similar to participants in Wave 1 and also to the national population (See table 1 below). For example, using weighted data, $49 \%$ of the sample was male at Wave 3, and $49 \%$ was male at Wave 1 . Seventy-three percent identified as White race at Wave 3 and $71 \%$ at Wave 1. Twenty-five percent lived in a household with an annual income of $\$ 35,000$ or less at Wave 3 versus $26 \%$ at Wave 1 .

\begin{tabular}{|c|c|c|c|}
\hline $\begin{array}{l}\text { Youth and Household } \\
\text { Demographic Characteristics }\end{array}$ & $\begin{array}{c}\text { Wave } 1 \\
(\mathrm{n}=1,577) \\
\%(\mathrm{n})\end{array}$ & $\begin{array}{c}\text { Wave } 2 \\
(\mathrm{n}=1,189) \\
\%(\mathrm{n})\end{array}$ & $\begin{array}{c}\text { Wave } 3 \\
(\mathrm{n}=1,149) \\
\%(\mathrm{n})\end{array}$ \\
\hline \multicolumn{4}{|l|}{ Sex } \\
\hline Female & $51.0(785)$ & $50.3(589)$ & $50.8(568)$ \\
\hline Male & $49.0(792)$ & $49.7(600)$ & $49.2(581)$ \\
\hline Age (mean) & 12.6 & 13.7 & 14.5 \\
\hline \multicolumn{4}{|l|}{ Race } \\
\hline White & $71.3(1155)$ & $73.9(900)$ & $72.5(855)$ \\
\hline Black or African American & $13.6(213)$ & $12.5(140)$ & $13.6(145)$ \\
\hline Mixed racial background & $8.6(113)$ & $7.5(80)$ & $8.2(84)$ \\
\hline All other & $6.5(96)$ & $6.1(69)$ & $5.7(65)$ \\
\hline Hispanic ethnicity & $18.1(206)$ & $16.7(144)$ & $16.6(137)$ \\
\hline \multicolumn{4}{|l|}{ Annual household income } \\
\hline$<\$ 35,000$ & $25.7(399)$ & $24.3(251)$ & $24.8(241)$ \\
\hline$\$ 35,000-\$ 74,999$ & $39.7(685)$ & $40.1(525)$ & $38.6(490)$ \\
\hline$\$ 75,000+$ & $34.6(493)$ & $35.6(413)$ & $36.7(418)$ \\
\hline
\end{tabular}

Table 1. A comparison of demographic charactaeristics of respondents across waves

\subsection{Measures}

Respondents were asked about bullying victimization as well as perpetration using Olweus' definition of bullying (Olweus, 1994): "We say a young person is being bullied or harassed when someone else or a group of people repeatedly hits, kicks, threatens, or says nasty or unpleasant things to them. Another example is when no one ever talks to them. These things 
can happen at school, online, or other places young people hang out. It is not bullying when two young people of about the same strength fight or tease each other. How often has this happened to you in the following environments?): 1) at school, 2) on the Internet, 3) on cell phones through text messaging, 4) on the way to and from school, and 5) somewhere else. For each environment, response options were: every day / almost every day; once or twice a week; once or twice a month; less often than once a month; never; and decline to answer.

Youth who reported bullying victimization in at least one environment were asked two follow up questions. First, these youth were asked to indicate how they felt when they were bullied in each environment, when thinking about the most serious incident. Responses were captured on a 5-point scale: not at all upset; somewhat upset; upset; very upset; extremely upset; and decline to answer. Second, youth were asked whether they knew their bully: "By "know" we mean you can recognize the person or you know who they are". Response options were: yes, no, not sure, and decline to answer.

Unwanted sexual experiences also were measured using parallel items for experiences when online, and experiences when at school. Note that other environments, including on the way to and from school, and 'somewhere else' were not queried. Text messaging-based experiences were queried, but using different measures and therefore are not included in the current analyses. Items were based upon those included in and referred to as "unwanted sexual solicitation" in the Youth Internet Safety Surveys (Finkelhor, Mitchell, \& Wolak, 2000; Wolak et al., 2006). We choose to call these experiences "unwanted sexual experiences" to avoid connotation that these youth were necessarily solicited for sex. Youth endorsing at least one of the following questions were classified as having an unwanted sexual experience: 1) Someone tried to get me to talk about sex when I did not want to; 2) Someone asked me for sexual information about myself when I did not want to tell the person, e.g., really personal questions, like what my body looks like or sexual things I have done; 3) Someone asked me to do something sexual that I did not want to do. Response options were: everyday/almost every day; once or twice a week; once or twice a month; a few times a year; less than a few times a year; never; and decline to answer. Perpetration was asked solely for the online environment. Similarly, distress was only queried for youth reporting victimization online. Given that the focus of the current paper is comparisons across environments, these data are not reported.

\subsection{Data cleaning and statistical analyses}

Data cleaning indicated that 18 youth were likely 9 years of age, and 12 youth were 16 years of age at Wave 1. To maximize the amount of data; and because caregivers did not know the eligibility criteria (and, therefore, were unlikely to have misreported their child's age purposefully), these youth are included in the analyses.

Data were weighted statistically to reflect the population of adults with children aged 10-15 years old in the U.S. in 2006 (when the sample was first recruited) according to adult age, sex, race/ethnicity, region, education, household income, and child age and sex.(Bureau of Labor Statistics \& Bureau of the Census, 2006) Adults were the weighting target as they were the ones first recruited into the survey. Survey sampling weights also adjust for adult respondents' self-selection into the HPOL (Berrens et al., 2003; Berrens et al., 2004; Schonlau et al., 2004; Taylor et al., 2001) as well as any differential follow-up of youth participants over time. 
Missing data and "refused" responses were imputed using best-set regression (StataCorp, 2008). To reduce the likelihood of imputing truly non-responsive answers, participants were required to have valid data for at least $85 \%$ of the survey questions asked of all youth. Eleven respondents did not meet this criterion and were dropped from the Wave 1 sample; 17 were dropped from the Wave 2 and 10 from the Wave 3 samples.

Statistical comparisons across environments cannot be made because categories are not exclusive; youth can be represented in multiple categories.

\section{Results}

\subsection{One-year prevalence rates across environments}

\subsubsection{Bully victimization}

\begin{tabular}{|c|c|c|c|c|c|}
\hline \multirow[b]{2}{*}{ Frequency } & \multicolumn{5}{|c|}{ Environment } \\
\hline & $\begin{array}{c}\text { School } \\
(\mathrm{n}=1,149) \\
\%(\mathrm{n})\end{array}$ & $\begin{array}{c}\text { Internet } \\
(\mathrm{n}=1,149) \\
\%(\mathrm{n})\end{array}$ & $\begin{array}{c}\text { Cell phone text } \\
\text { messaginga } \\
(\mathrm{n}=806) \\
\%(\mathrm{n})\end{array}$ & $\begin{array}{c}\text { To and From } \\
\text { school } \\
(\mathrm{n}=1,149) \\
\%(\mathrm{n}) \\
\end{array}$ & $\begin{array}{c}\text { Somewhere } \\
\text { else } \\
(\mathrm{n}=1,149) \\
\%(\mathrm{n}) \\
\end{array}$ \\
\hline $\begin{array}{l}\text { Every day / almost every } \\
\text { day }\end{array}$ & $1.3(15)$ & $0.3(4)$ & $0.4(1)$ & $0.9(3)$ & $0.3(3)$ \\
\hline Once or twice a week & $4.0(43)$ & $0.3(5)$ & $0.5(6)$ & $1.7(16)$ & $1.5(13)$ \\
\hline Once or twice a month & $3.2(46)$ & $1.9(22)$ & $1.7(13)$ & $1.1(15)$ & $1.9(22)$ \\
\hline Less often & $22.1(254)$ & $12.3(150)$ & 9.5 (73) & $7.8(88)$ & 10.8 (114) \\
\hline Never & $69.4(791)$ & $85.3(968)$ & $88.2(713)$ & $89.2(1027)$ & $85.6(997)$ \\
\hline
\end{tabular}

${ }^{a}$ Restricted to youth who sent and received text messages at least once in the past year $(70 \%, n=806)$

Table 2. A comparison of 1-year bullying victimization rates across environments

Overall, $40 \%$ of youth reported some bully victimization in the past year. Rates across environments are shown in Table 2. An examination of the school-online overlap suggests that most of these youth were bullied at school exclusively: $59 \%$ were bullied only at school; $13 \%$ were bullied only online; and $28 \%$ were bullied both at school and online

\subsubsection{Bully perpetration}

\begin{tabular}{lccccc}
\hline Frequency & \multicolumn{5}{c}{ Environment } \\
\cline { 2 - 6 } & $\begin{array}{c}\text { School } \\
(\mathrm{n}=1,149) \\
\%(\mathrm{n})\end{array}$ & $\begin{array}{c}\text { Internet } \\
(\mathrm{n}=1,149) \\
\%(\mathrm{n})\end{array}$ & $\begin{array}{c}\text { Cell phone text } \\
\text { messaginga } \\
(\mathrm{n}=806) \\
\%(\mathrm{n})\end{array}$ & $\begin{array}{c}\text { To and From } \\
\text { school } \\
(\mathrm{n}=1,149) \\
\%(\mathrm{n})\end{array}$ & $\begin{array}{c}\text { Somewhere } \\
\text { else } \\
(\mathrm{n}=1,149) \\
\%(\mathrm{n})\end{array}$ \\
\hline $\begin{array}{l}\text { Every day / almost every } \\
\text { day }\end{array}$ & $0.3(5)$ & $0.06(2)$ & $0.3(2)$ & $0.03(1)$ & $0.4(3)$ \\
Once or twice a week & $1.3(13)$ & $0.6(7)$ & $0.9(6)$ & $0.9(8)$ & $1.2(11)$ \\
Once or twice a month & $1.7(22)$ & $0.8(15)$ & $1.0(11)$ & $0.3(8)$ & $1.2(15)$ \\
Less often & $10.4(107)$ & $4.7(47)$ & $3.4(25)$ & $3.0(34)$ & $3.4(44)$ \\
Never & $86.4(1002)$ & $93.7(1078)$ & $94.3(762)$ & $95.8(1098)$ & $93.8(1076)$ \\
\hline
\end{tabular}

${ }^{a}$ Restricted to youth who sent and received text messages at least once in the past year $(70 \%, n=806)$

Table 3. A comparison of 1-year bullying perpetration rates across environments 
Eighteen percent of youth reported being bullies in the past year. Table 3 shows bullying rates by environment. The school-online overlap was similar to that noted for victims: among youth who bullied in either place, 59\% bullied only at school, 10\% bullied only online, and $31 \%$ bullied both online and at school.

\section{\# of different environments youth are victimized by bullying}

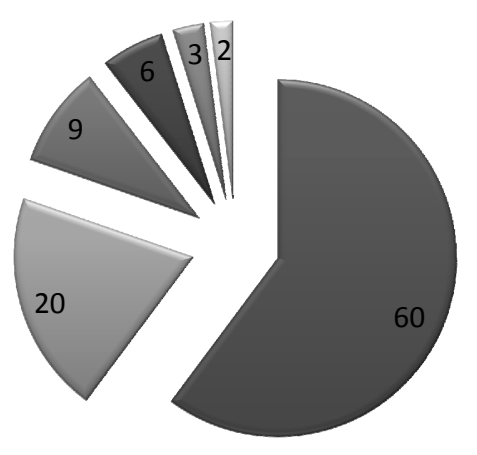

$\begin{array}{ll}\square 0 \text { environments } & \square 1 \text { environment } \\ \square 2 \text { environments } & \square 3 \text { environments } \\ \square 4 \text { environments } & \square 5 \text { environments }\end{array}$

\section{\# of different environments youth perpetrate bullying}

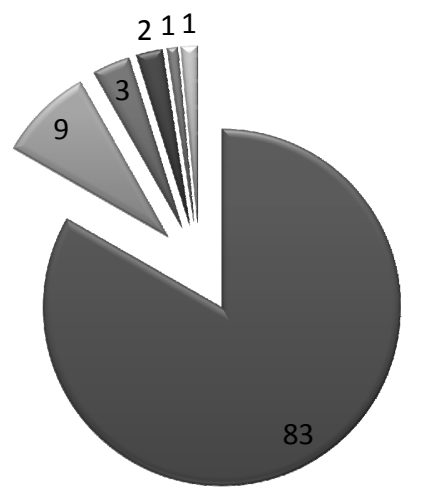
0 environments
$\square 1$ environment
$\square 2$ environments
3 environments
$\square 4$ environments
$\square 5$ environments

Fig. 1. Overlap of bullying experiences across environments

As shown in the Figure, the majority of youth were not victims $(60 \%)$ or perpetrators $(82 \%)$ of bullying in any environment. For those who were involved in bullying, the most common experience was victimization $(20 \%)$ or perpetration $(9 \%)$ in one environment. Fewer reported being victimized $(9 \%)$ or perpetrating $(4 \%)$ across two environments. Very few reported being bullied or bullying others in four or all five of the environments queried.

\subsubsection{Unwanted sexual experiences}

\begin{tabular}{lcc}
\hline \multirow{2}{*}{ Frequency } & \multicolumn{2}{c}{ Environment } \\
\cline { 2 - 3 } & $\begin{array}{c}\text { School } \\
(\mathrm{n}=1,149)\end{array}$ & $\begin{array}{c}\text { Internet } \\
(\mathrm{n}=1,149) \\
\%(\mathrm{n})\end{array}$ \\
\hline Every day / almost every day & $0.2(5)$ & $0.4(7)$ \\
Once or twice a week & $1.7(14)$ & $1.3(9)$ \\
Once or twice a month & $2.1(17)$ & $2.9(29)$ \\
Less often & $13.7(169)$ & $13.0(154)$ \\
Never & $82.3(944)$ & $82.4(950)$ \\
\hline
\end{tabular}

Table 4. 1-year unwanted sexual experiences victimization rates across environments 
Almost one in four youth (25\%) reported being victims of unwanted sexual experiences in the past year. As show in Table 4,18\% of youth reported unwanted sexual experiences at school, and $18 \%$ online. Among victims, $29 \%$ reported being victimized at school only, $29 \%$ online only, and $42 \%$ both at school and online.

\subsection{The bully victimization "experience" across environments}

\subsubsection{Distress}

Youth who reported being bullied were asked to indicate how they felt about the most serious incident in each environment they were bullied. As shown in Table 5, more youth reported being upset by their most serious bullying incident at school (37.5\%) than any other environment.

\begin{tabular}{lll}
\hline Environment & $\begin{array}{c}\text { Very / extremely } \\
\text { upset by the most } \\
\text { serious incident } \\
\%(\mathrm{n})\end{array}$ & $\begin{array}{c}\text { Not sure / Do } \\
\text { not "know" the } \\
\text { bully } \\
\%(\mathrm{n})\end{array}$ \\
\hline School $(\mathrm{n}=358)$ & $37.5(128)$ & $12.0(44)$ \\
Internet $(\mathrm{n}=181)$ & $15.4(34)$ & $45.8(84)$ \\
Cell phone text messaging $(\mathrm{n}=95)$ & $32.9(28)$ & $29.0(23)$ \\
$\begin{array}{l}\text { On the way to and from school } \\
(\mathrm{n}=122)\end{array}$ & $38.8(46)$ & $22.4(25)$ \\
Somewhere else $(\mathrm{n}=152)$ & $36.7(56)$ & $27.2(46)$ \\
\hline
\end{tabular}

Table 5 . The bully victimization expereince: Victim distress and knowing one's perpetrator $(\mathrm{n}=1,149)$

\subsubsection{Knowing one's perpetrator}

When asked to indicate if they "knew" the bully (i.e., the respondent could recognize the bully or knew who they were), almost half (46\%) of youth bullied online said they were not sure or did not know who the bully was (see Table 5). About one in four youth said they were unsure or did not know their bully via text messaging $(29 \%)$ and one in three said they were unsure or did not know their bully on the way to and from school $(22 \%)$. Slightly more than one in ten youth bullied at school $(12 \%)$ said they did not know or were unsure about the bully's identity.

\section{Discussion}

Based upon data from 12-17 year-olds surveyed nationally, involvement in bullying and unwanted sexual experiences appears common: $40 \%$ report being bullied, 18\% report bullying, and 25\% report being victims of unwanted sexual experiences in at least one environment that they navigate. Although it is difficult to compare these data with previous studies that have focused more specifically on experiences occurring either at school or online, it is fair to say that our findings provide further evidence that involvement in youth aggression, either as a perpetrator or as a victim, is widespread. 


\subsection{School bullying is more common than online bullying}

Bullying is reported more frequently at school than online: $31 \%$ of youth report being bullied at school compared to $15 \%$ online; bully perpetration is reported by $14 \%$ of youth at school compared to $6 \%$ who bully others online. Moreover, an examination of the schoolonline overlap suggests that most youth are bullied or bully at school exclusively. Youth spend more hours in close immediate proximity with peers at school then they do at home or in their neighborhoods in the evening. Interactions in school are inherently social and the opportunities for conflict are plentiful (e.g., hallways, lunch, recess). It is not clear that online environments provide the same amount of time to bully others. Also too, school bullying is often perpetrated by individuals and groups of individuals with an audience present (O'Connell, Pepler, \& Craig, 1999; Salmivalli, Lagerspetz, Björkqvist, Österman, \& Kaukiainen, 1996) in order to promote the bully's popularity or maintain his or her high social status. The audience reinforces the behavior, thereby increasing the likelihood that it will continue. Although there is an audience online (e.g., Facebook), it is not clear what role this audience plays or how strongly their reinforcement is as it is being mediated through a computer screen. Perhaps part of the reason rates are higher at school is because the social reinforcement is stronger there.

\subsection{School bullying is more distressing than online bullying}

Online bullying may be different or more distressing than offline bullying because of the ability to hide one's identity, and the rapidity and breadth with which the information is disseminated. Our data do not support this hypothesis, however. Twice as many youth bullied at school (38\%) indicate that they feel very or extremely upset by the most serious incident compared to youth bullied online (15\%). Moreover, while many more youth (46\%) report not knowing their bully online compared to school, $12 \%$ report they do not know their bully at school. It seems that the differential power inherent in keeping one's identity secret is more commonly utilized online, but it is possible offline as well (e.g., rumors spread around school).

\subsection{Bullying happens other places as well}

Importantly, $11 \%$ of youth report being bullied on the way to and from school, and $14 \%$ "somewhere else"; $4 \%$ and $6 \%$ report bullying perpetration in these respective environments. This serves as a useful reminder that the online/offline discussion does not implicitly mean online/school. Young people have to safely navigate a multitude of environments each day. Our challenge as researchers is to understand how the experiences of youth are similar and different by environment so that our public policy initiatives and interventions can be general when appropriate and environment-specific when need be.

\subsection{Few youth have a never-ending bullying experience}

Another concern some have is that technology has created a world in which victims cannot hide from bullies. This may be the case for some youth, but it does not appear to be the common experience. Most youth are not involved in bullying at all. Among victimized youth, the most common victimization experience is being victimized in one versus multiple 
environments, with school being the one environment most often reported. This suggests that for the majority of youth who are involved in bullying, it is not necessarily something that follows them from the time they wake to the tiime they go to sleep. Nonetheless, there is a very concerning $5 \%$ of youth who report being bullied and $2 \%$ who report bullying others in four or all five of the environments we queried. Certainly, for these youth, bullying is an experience that likely seems inescapable. Given that they are bullied in multiple environments, this may mean that there are more opportunities to reach them with support and other intervention efforts. It is essential to take steps to identify and target this group of kids.

\subsection{Unwanted sexual experiences happen at school and online with equal frequency}

Certainly, unwanted sexual encounters happening online have received the majority of academic research attention (Mitchell et al., 2001, 2007; Ybarra et al., 2004). A study conducted in 2000 among 2064 8-12th graders attending public school (American Association of University Women Educational Foundation, 2001) suggests that eight in ten students experience sexual harassment at school sometime in their lives. Rates of unwanted sexual experiences in the past year in the current study are the same at school (18\%) and online $(18 \%)$. Efforts to recognize and reduce unwanted sexual experiences in the schools need to receive just as much attention as those focused online.

While with good intention, recent public policy efforts to regulate social networking sites to reduce the risk of unwanted sexual encounters for adolescents (Berkman Center for Internet \& Society at Harvard University, 2008) may not reach youth who are most vulnerable. Unlike bullying, youth who are victims of unwanted sexual experiences are more likely to report being targeted both online and at school $(42 \%)$ compared to youth targeted at school only (29\%) or online only (29\%). Future research should focus on these dually-involved youth to better understand who they are and what researchers and other professionals working with adolescents might do to reduce their vulnerability online as well as offline.

\subsection{Study limitations and strengths}

This paper is the first to report rates of bullying involvement and unwanted sexual experiences online and offline, in school and out of school, using parallel measures among youth in a national US sample. It also is the first to report relative rates of distress and the frequency of "knowing" the perpetrator among bully victims. It is not however, without limitation. The measures for unwanted sexual experiences are less comprehensive than those for bullying. It is possible that the general prevalence rate for unwanted sexual experiences would be higher if other environments (e.g., cell phone text messaging) were queried. It also is possible that caregivers monitored their children while they were completing the survey. This may have led to under-reporting, although comparisons across environments should still hold as there is little reason to believe youth would be more willing to report bullying at school versus online, for example. The sample is based upon English-speaking households. Findings are not generalizable to households that do not read English. 


\subsection{Future research implications}

Environments were queried with the assumption that they were distinct. With the convergence of technology, it is possible now for youth to be bullied on their Facebook profiles, which they could access on their web-capable cell phones during a break at school. In this scenario, youth could potentially click on all three 'environments'. Future research should focus on the conundrum of whether, and if so, how to disentangle these converging environments. This would improve our ability to compare prevalence rates of bullying across the environments in which young people live in order to better target scarce prevention dollars more effectively. It may be however that the "online" "offline" lines have so blurred that the question will quickly become 'have you been bullied', without respect to 'where'. The future challenge for researchers will be to determine when technology is an important characteristic to measure and when it is not.

\section{8 'Real world' implications}

With youth more likely to be involved in bullying as a victim or perpetrator at school versus online, programs need to continue to prevent and intervene on bullying behavior within schools. Certainly, schools are appropriately working to create protocols that address cyberaggression and harassment. These prevention efforts should not replace programs that address face-to-face bullying, however; instead, they should be viewed as adjuncts to existing programming. Bullying experiences online could be incorporated into bully prevention programs by simply defining bullying online as bullying which is communicated through the online context.

The relative frequency of sexual harassment both at school and online speaks to the need for prevention programs at the school level. In contrast to the vigilance paid to bullying, sexual harassment is not a commonly discussed adolescent behavior. As noted above, this needs to change.

\section{Conclusion}

Data from 12-17 year olds nationally suggest that youth are more likely to be involved in bullying at school compared to online, on the way to and from school, and all other environments youth must navigate each day. They are as likely to be a victim of unwanted sexual experiences at school as online. Among bullied youth, $38 \%$ were very or extremely upset by their most serious bullying experience at school compared to $15 \%$ online. These data do not support a hypothesis that the Internet is introducing a more dangerous environment for youth, nor do they support the supposition that online victimization experiences are more distressing overall.

\section{Acknowledgment}

The Growing up with Media study was supported by Cooperative Agreement Number U49/CE000206 from the Centers for Disease Control and Prevention (CDC). The contents of this publication are solely the responsibility of the authors and do not necessarily represent the official views of the CDC. The funders were involved in the design and conduct of the 
study. They were not responsible for data collection, management, analysis, and interpretation of the data; nor were they involved in the preparation, review, or approval of the manuscript.

We would like to thank the entire Growing up with Media Study team from Internet Solutions for Kids, Harris Interactive, Johns Hopkins Bloomberg School of Public Health, and the Centers for Disease Control and Prevention, who contributed to the planning and implementation of the study. Finally, we thank the families for their time and willingness to participate in this study.

\section{References}

American Association of University Women Educational Foundation. (2001). Hostile hallways: Bullying, teasing, and sexual harassment in school. Washington, DC: AAUW Educational Foundation. Retrieved from http://www.aauw.org/learn/research/upload/hostilehallways.pdf

Berkman Center for Internet \& Society at Harvard University. (2008). Enhancing Child Safety E Online Technologies: Final Report of the Internet Safety Technical Taskforce to the Multi-State Working Group on Social Networking of State Attorneys General of the United States. Cambridge, MA: The Berkman Center for Internet \& Society, Harvard University. Retrieved from http://cyber.law.harvard.edu/pubrelease/isttf/

Berrens, R. P., Bohara, A. K., Jenkins-Smith, H., Silva, C., \& Weimer, D. L. (2003). The advent of Internet surveys for political research: A comparison of telephone and Internet samples. Political Analysis, 11(1), 1-22. doi: 10.1093/pan/11.1.1

Berrens, R. P., Bohara, A. K., Jenkins-Smith, H. C., Silva, C. L., \& Weimer, D. L. (2004). Information and effort in contingent valuation surveys: Application to global climate change using national internet samples. Journal of Environmental Economics E Management, 47(2), 331-363. doi: 10.1016/S0095-0696(03)00094-9

Bureau of Labor Statistics, \& Bureau of the Census. (2006). Current Population Survey Retrieved July 5, 2006, from

http://www.bls.census.gov/cps/cpsmain.htm

Cook, C., Heath, F., \& Thompson, R. L. (2000). A meta-analysis of response rates in web- or Internet-based surveys. Educational and Psychological Measurement, 60(6), 821-836. doi: $10.1177 / 00131640021970934$

Due, P., Holstein, B. E., Lynch, J., Diderichsen, F., Gabhain, S. N., Scheidt, P., ... Health Behaviour in School-Aged Children Bullying Working Group. (2005). Bullying and symptoms among school-aged children: International comparative cross sectional study in 28 countries. European Journal of Public Health, 15(2), 128-132. doi: 10.1093/eurpub/cki105

Fineran, S., \& Bolen, R. M. (2006). Risk factors for peer sexual harassment in schools. Journal of Interpersonal Violence, 21(9), 1169-1190. doi: 10.1177/0886260506290422 
Finkelhor, D., Mitchell, K. J., \& Wolak, J. (2000). Online victimization: A report on the nation's youth. (6-00-020). Alexandria, VA: National Center for Missing \& Exploited Children. Retrieved from http://www.unh.edu/ccrc/pdf/jvq/CV38.pdf

Guan, S. S., \& Subrahmanyam, K. (2009). Youth Internet use: Risks and opportunities. Current Opinions in Psychiatry, 22(4), 351-356. doi: 10.1097/YCO.0b013e32832bd7e0

Harris Interactive. (2006). Online methodology Retrieved July 5, 2006, from http://www.harrisinteractive.com/partner/methodology.asp

Hawker, D. S. J., \& Boulton, M. J. (2000). Twenty years' research on peer victimization and psychosocial maladjustment: A meta-analytic review of cross-sectional studies. Journal of Child Psychology and Psychiatry, 41(4), 441-455. doi: 10.1111/14697610.00629

Juvonen, J., \& Gross, E. F. (2008). Extending the school grounds? - Bullying experiences in cyberspace. Journal of School Health, 78(9), 496-505. doi: 10.1111/j.17461561.2008.00335.x

Kaplowitz, M. D., Hadlock, T. D., \& Levine, R. (2004). A comparison of web and mail survey response rates. Public Opinion Quarterly, 68(1), 94-101. doi: $10.1093 / \mathrm{poq} / \mathrm{nfh} 006$

Katzer, C., Fetchenhauer, D., \& Belschak, F. (2009). Cyberbullying: Who are the victims? A comparison of victimization in Internet chatrooms and victimization in school. Journal of Media Psychology, 21(1), 25-36. doi: 10.1027/1864-1105.21.1.25

Lenhart, A. (2009). Teens and mobile phones over the past five years: Pew Internet looks back. Washington, DC: Pew Internet \& American Life Project. Retrieved from http:/ / www.pewinternet.org/Reports/2009/14--Teens-and-Mobile-Phones-DataMemo.aspx

Li, Q. (2006). Cyberbullying in schools: A research of gender differences. School Psychology International, 27(2), 157-170. doi: 10.1177/0143034306064547

Mitchell, K. J., Finkelhor, D., \& Wolak, J. (2001). Risk factors for and impact of online sexual solicitation of youth. Journal of the American Medical Association, 285(23), 3011-3014. doi: 10.1001/jama.285.23.3011

Mitchell, K. J., Finkelhor, D., \& Wolak, J. (2007). Youth internet users at risk for the most serious online sexual solicitations. American Journal of Preventive Medicine, 32(6), 532-537. doi: 10.1016/j.amepre.2007.02.001

Nansel, T., Craig, W., Overpeck, M., Saluja, G., Ruan, W. J., \& Health Behavior in School-aged Children Bullying Working, G. (2004). Cross-national consistency in the relationship between bullying behaviors and psychosocial adjustment. Archives of Pediatrics \& Adolescent Medicine, 158(8), 730-736. doi: 10.1001/archpedi.158.8.730

O'Connell, P., Pepler, D., \& Craig, W. (1999). Peer involvement in bullying: insights and challenges for intervention. Journal of Adolescence, 22(4), 437-452. doi: 10.1006/jado.1999.0238

Olweus, D. (1994). Annotation: Bullying at School: Basic facts and effects of a school based intervention program. Journal of Child Psychology and Psychiatry, 55(7), 1171-1190. doi: 10.1111/j.1469-7610.1994.tb01229.x 
Raskauskas, J., \& Stoltz, A. D. (2007). Involvement in traditional and electronic bullying among adolescents. Developmental Psychology, 43(3), 564-575. doi: 10.1037/00121649.43.3.564

Rideout, V. J. (2001). Generation Rx.com: How young people use the Internet for health information. Washington, DC: The Henry J. Kaiser Family Foundation. Retrieved from http://www.kff.org/entmedia/20011211a-index.cfm

Salmivalli, C., Lagerspetz, K., Björkqvist, K., Österman, K., \& Kaukiainen, A. (1996). Bullying as a group process: Participant roles and their relations to social status within the group. Aggressive Behavior, 22(1), 1-15. doi: 10.1002/(sici)1098-2337(1996)22:1<1::aidab1>3.0.co;2-t

Schonlau, M., Zapert, K., Simon, L. P., Sanstad, K. H., Marcus, S. M., Adams, J., Spranca, M., Berry, S. H. (2004). A comparison between response from a propensity-weighted Web survey and an identical RDD survey. Social Science Computer Review, 22(1), 128-138. doi: $10.1177 / 0894439303256551$

Slonje, R., \& Smith, P. K. (2008). Cyberbullying: Another main type of bullying? Scandinavian Journal of Psychology, 49(2), 147-154. doi: 10.1111/j.1467-9450.2007.00611.x

Smith, P. K., Mahdavi, J., Carvalho, M., Fisher, S., Russell, S., \& Tippett, N. (2008). Cyberbullying: its nature and impact in secondary school pupils. Journal of Child Psychology and Psychiatry, 49(4), 376-385. doi: 10.1111/j.14697610.2007.01846.x

Sourander, A., Helstela, L., Helenius, H., \& Piha, J. (2000). Persistence of bullying from childhood to adolescence--a longitudinal 8-year follow-up study. Child Abuse $\mathcal{E}$ Neglect, 24(7), 873-881. doi: 10.1016/S0145-2134(00)00146-0

StataCorp. (2008). Stata Statistical Software (Version 10.1). College Station, TX: Stata Corporation.

Taylor, H., Bremer, J., Overmeyer, C., Siegel, K. W., \& Terhanian, G. (2001). The record of internet-based opinion polls in predicting the results of 72 races in the November 2000 US elections. International Journal of Market Research, 43, 1-8.

Wang, J., Iannotti, R. J., \& Nansel, T. R. (2009). School bullying among adolescents in the United States: Physical, verbal, relational, and cyber. Journal of Adolescent Health, 45(4), 368-375. doi: 10.1016/j.jadohealth.2009.03.021

Wolak, J., Mitchell, K. J., \& Finkelhor, D. (2006). Online victimization of youth: 5 years later. (0706-025). Alexandria, VA: National Center for Missing \& Exploited Children. Retrieved from http://www.unh.edu/ccrc/pdf/CV138.pdf

Ybarra, M., Diener-West, M., \& Leaf, P. (2007a). Examining the overlap in Internet harassment and school bullying: Implications for school intervention. Journal of Adolescent Health, 41(6 Suppl 1), S42-S52. doi: 10.1016/j.jadohealth.2007.09.004

Ybarra, M., Leaf, P., \& Diener-West, M. (2004). Sex differences in youth-reported depressive symptomatology and unwanted internet sexual solicitation. Journal of Medical Internet Research, 6(1), e5. doi: 10.2196/jmir.6.1.e5

Ybarra, M., \& Suman, M. (2008). Reasons, assessments, and actions taken: Sex and age differences in uses of Internet health information. Health Education Research, 23(3), 512-521. doi: 10.1093/her/cyl062 
Ybarra, M. L., Espelage, D. L., \& Mitchell, K. J. (2007b). The co-occurrence of Internet harassment and unwanted sexual solicitation victimization and perpetration: Associations with psychosocial indicators. Journal of Adolescent Health, 41(6 Suppl 1), S31-41. doi: 10.1016/j.jadohealth.2007.09.010 


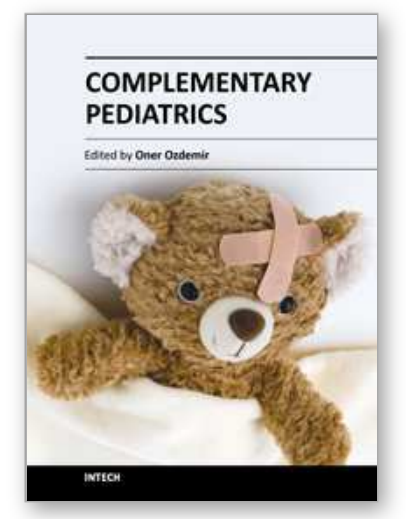

\author{
Complementary Pediatrics \\ Edited by Dr. Öner Özdemir
}

ISBN 978-953-51-0155-0

Hard cover, 354 pages

Publisher InTech

Published online 16, March, 2012

Published in print edition March, 2012

Complementary Pediatrics covers complementary issues of pediatric subspecialties consisting of ophthalmologic, surgical, psychosocial and administrative issues of frequently used medications. This book volume with its 16 chapters will help get us and patients enlightened with the new developments on these subspecialties' area.

\title{
How to reference
}

In order to correctly reference this scholarly work, feel free to copy and paste the following:

Michele L. Ybarra, Kimberly J. Mitchell and Dorothy L. Espelage (2012). Comparisons of Bully and Unwanted Sexual Experiences Online and Offline Among a National Sample of Youth, Complementary Pediatrics, Dr. Öner Özdemir (Ed.), ISBN: 978-953-51-0155-0, InTech, Available from:

http://www.intechopen.com/books/complementary-pediatrics/comparisons-of-bully-and-unwanted-sexualexperiences-online-and-offline-among-a-national-sample-of-y

\section{INTECH}

open science | open minds

\author{
InTech Europe \\ University Campus STeP Ri \\ Slavka Krautzeka 83/A \\ 51000 Rijeka, Croatia \\ Phone: +385 (51) 770447 \\ Fax: +385 (51) 686166 \\ www.intechopen.com
}

\author{
InTech China \\ Unit 405, Office Block, Hotel Equatorial Shanghai \\ No.65, Yan An Road (West), Shanghai, 200040, China \\ 中国上海市延安西路65号上海国际贵都大饭店办公楼 405 单元 \\ Phone: +86-21-62489820 \\ Fax: $+86-21-62489821$
}


(C) 2012 The Author(s). Licensee IntechOpen. This is an open access article distributed under the terms of the Creative Commons Attribution 3.0 License, which permits unrestricted use, distribution, and reproduction in any medium, provided the original work is properly cited. 